УДК $581.55+581.524 .34$

DOI: $10.37482 / 0536-1036-2021-3-37-48$

\title{
ASSESSMENT OF NATURAL AND FOREST RECLAIMED FORAGE LANDS IN SEMI-DESERT CONDITIONS IN SOUTHERN RUSSIA
}

Ludmila P. Rybashlykoval, Candidate of Agriculture, Leading Research Scientist; ResearcherID: W-4197-2018, ORCID: https://orcid.org/0000-0002-3675-6243

Vladimir V. Lepesko' ${ }^{2}$, Candidate of Agriculture, Leading Research Scientist; ResearcherID: AAD-9953-2020, ORCID: https://orcid.org/0000-0003-2111-9636

${ }^{1}$ Federal Scientific Centre of Agroecology, Complex Melioration, and Protective Afforestation, Russian Academy of Sciences, prosp. Universitetskiy, 97, Volgograd, 400062, Russian Federation; e-mail: ludda4ka@mail.ru

${ }^{2}$ Bogdinskaya Research Agroforestry Experimental Station, ul. BOS, 1, Kharabali, Astrakhan Region, 416010, Russian Federation

\begin{abstract}
Haphazard use of pastures has become one of the factors of disturbance of their natural vegetation. Therefore, forest reclamation works were carried out and significant areas of strip plantations of shrubs were created in the Caspian Sea region in the mid-20th century. In the arid zone of Russia, one of the most important tasks in the field of scientific provision of protective afforestation is the improvement of methods and techniques of arrangement, increasing longevity and environmental, agricultural, and utilitarian efficiency of plantations. This study aims to determine the long-term impact of afforestation on the functioning of pasture ecosystems. The influence of tree and shrub layer on biodiversity and productivity of vegetation cover of pastures was also studied. The research objects are plantations growing on the reclaimed pastures. The research is based on the materials of biomonitoring and field experiments using standard methods of forest inventory and geobotanical survey. Rectangular-shaped test plots of $0.25-0.30$ ha were laid out for the study of forest plots. Test plots were used for a detailed description of the location, soil composition, time, method, and technology of plantation development, as well as a comprehensive assessment of the growth and longevity of tree and shrub crops. Data from key plots were used to study the successional processes of vegetation cover. The research results have shown that deep plowing preparation of soil to obtain high results in rooting, preservation, and growth of shrub species has an advantage over other soil preparation technologies in the semi-desert zone. It was found that the shrub layer up to 45 years old retains its productive and generative abilities. Pasture protection belts from Haloxylon aphyllum and reclamation and fodder plantations from Krascheninnikovia ceratoides and Calligonum aphyllum have a high cenosis potential and stability. In this case study, in semi-arid regions, afforestation with shrubs is the best way to improve and restore pastures.

For citation: Rybashlykova L.P., Lepesko V.V. Assessment of Natural and Forest Reclaimed Forage Lands in Semi-Desert Conditions in Southern Russia. Lesnoy Zhurnal [Russian Forestry Journal], 2021, no. 3, pp. 37-48. DOI: 10.37482/0536-1036-2021-3-37-48
\end{abstract}

Keywords: arid zone, brown soils, forest pastures, geobotanical descriptions, multi-layered structure of phytocenoses, reclaimed forage lands, semi-desert.

\section{Introduction}

Further development of sheep breeding within pastures of the arid zone is impossible without strengthening the forage base, which is based on the rational use of reclaimed and natural forage lands. Vegetation cover is closely related to natural conditions and the economic use of the territory. Natural semi-desert pastures in the

Авторы заявляют об отсутствии конфликта интересов / The authors declare that there is no conflict of interest 
region are characterized by low yields $(0.15-0.35 \mathrm{t} / \mathrm{ha})[6,15]$ and sharp differences in forage reserves by year and season [17], which restrains the rate of animal husbandry development.

Uncontrolled cattle grazing leads to the reduction and disappearance of valuable forage plants from the grass plantations (Kochia prostrata L., Agropyron fragile Roth., Camphorosma lessisingii Litv. and other species), destruction of the fertile soil layer, and development of land degradation [18, 20].

As a rule, low-value forage annual plants and pasture perennial weeds (Peganum harmala L., Euphorbia virgate Waldst. \& Kit, Anabasis aphylla L.) settle in places where primary vegetation is destroyed, which leads to a reduction in forage reserves in pastures [13]. To prevent further deterioration of pastures, restore their natural productivity, and improve the quality of forage on pastures of the semi-desert zone, a set of measures is required to create systems of pasture protection and reclamationforage plantations from the most valuable in terms of protective and forage function shrub and tree species $[5,11,16]$.

Protective plantings create a more favorable zone for cattle grazing on pastures, the organization of grazing and load regulation is simplified [8].

Livestock keeping conditions are improving on forested pastures as forest plantations protect animals from heat, sun, dust storms, cold winds, and blizzards [4, 14].

Linear continuous strip plantations protect the pasture area from strong winds, which is important in cold weather conditions, since a decrease in wind speed moves the border of adverse cold from -4 to $0{ }^{\circ} \mathrm{C}$, for example, from $4 \mathrm{~m} / \mathrm{s}$ to $0 \mathrm{~m} / \mathrm{s}$ [9]. However, in summer when it is calm, sheep are oppressed by overheating at an air temperature of $22-27^{\circ} \mathrm{C}$, and the oppression is noted at a higher temperature $\left(25-29^{\circ} \mathrm{C}\right)$ with a wind speed of $4 \mathrm{~m} / \mathrm{s}$.

The creation of savanna and diffusor-screen plantations diversifies the ecology of pasture spaces by forming zones with different air exchange intensities, light conditions, and temperatures in the habitat of grazing animals [9].

The research purpose was to determine the stability and current state of tree and shrub plantations and assess their ecological and reclamation impact on pastures in semi-desert conditions.

The study of the functioning of reclaimed pasture and forest-pasture ecosystems is of theoretical and practical importance in optimal and, especially, extreme conditions of the arid zone [7, 19].

Modern phytocenoses of natural pastures of the Astrakhan semi-desert develop according to the wormwood-ephemeral type. They are degraded and phytocenotically incomplete. Ecological niches of highly nutritious plants are occupied by lowvalue (analogous) species, which indicates the duration of the impact of adverse environmental factors.

Studies conducted within the territory of the studied region revealed forest pastures that have retained their functional purpose and have existed for about 50 years, which made it possible to assess the long-term reclamation effect.

\section{Materials and methods}

The studied territory belongs to the Caspian subprovince and the North Turanian province of the Afro-Asian desert region according to phytogeographical zoning, and, in geomorphological terms, it is a marine plain of Late Khvalyn age, 
modified by the Baer knolls and Aeolian landforms, such as ridges, barkhans and semi-fixed dunes [10]. See the figure.

The proximity of the Caspian sea and the intersection of sandy areas from North-West to South-East by the Volga river has no noticeable mitigating effect. Total annual precipitation is $100-200 \mathrm{~mm}$. Mainly, low-snowy winters prevail, the thickness of the snow cover does not exceed $10-15 \mathrm{~cm}$. The continental climate is manifested in the amplitudes of summer, winter, and annual temperatures. The maximum temperature is $+42^{\circ} \mathrm{C}$. The minimum relative humidity during the growing season of plants is reduced to $10 \%$. Evaporation is very high $(950-1100 \mathrm{~mm})$ and exceeds atmospheric precipitation by 5-7 times. The average number of days with dry winds is 113 with a probability of $100 \%$ according to the data of the Kharabali hydrometeorological station.

Location of the study area

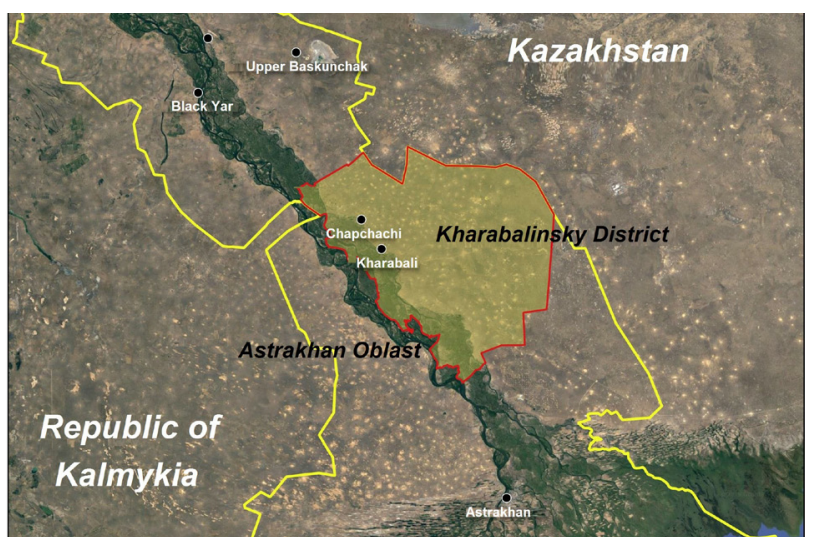

The assessment of successive changes was carried out within pasture areas of the arid zone, where phytoreclamation and forest reclamation works were performed in 1975-1980. The research objects are plantations growing on the reclaimed pastures. The Priselskiy pasture plot covers an area of 306 ha. Pasture protection strips consist of Haloxylon aphyllum Minkw. (106 ha, seedling planting in 1978), reclamationforage strips of Krascheninnikovia ceratoides L. and Calligonum aphyllum Pall. (200 ha, seedling planting in 1978). The terrain is a hilly plain that belongs to typical brown sandy loam soils. The plant association is ephemeral, with Artemisia lerchiana Weber ex Stechm. growing singly.

The Sokolovskiy pasture plot (213 ha) is represented by a hilly plain. It has a network of pasture protection strips with an area of 103 ha planted in 1976 and an area of 110 ha of pasture plantations of 1978. The soil is brown desert-steppe saline sandy loam and light loam in a complex with solonetz of $10 \%$.

The strips are 3-row, located across the prevailing winds. The width of the aisle is $4 \mathrm{~m}$. The plant association is multi-herbaceous (Barbarea vulgaris $\mathrm{R}$. Br., Poa bulbosa L., Elytrigia repens L., Artemisia arenaria DC., solitary A. lerchiana).

The Railway pasture plot (390 ha) is defined by a flat inter-mound depression. Planting on an area of 60 ha was carried out by the forest reclamation station in 1977, pasture protection strips $-100 \mathrm{ha}$, and pasturable strips $-230 \mathrm{ha}$. The soil is brown, sandy loam. Ground water is not revealed at a depth of $5 \mathrm{~m}$. Pasture protection strips are 3-row with a 4-meter aisle. The soil is prepared according to the deep plowing method. The main plant species is Haloxylon aphyllum. Three pasture strips of 
Krascheninnikovia ceratoides were planted into an inter-band space of 150-meter wide in 1980. The plant association varies from montley grass to white wormwood.

The Roadside pasture plot covers an area of 430 ha (100 ha in 1979 and 330 ha in 1981). The forest pastures were created on the Baer knolls, the soil is brown saline, sandy loam of II and III forest-reclamation category (FRC) and light loam in combination with solonetz of $10 \%$. The spaces between the strips are $30 \mathrm{~m}$. The plant association is wormwood-cereal (bluegrass).

The Cordon pasture plot consists of 8 pasture protection strips (100 ha). The strips are 3-row; the width of the aisles is $4 \mathrm{~m}$. The planting was carried out in 1977. Deep plowing was used for forest pasture strips. The inter-strip spaces are $30 \mathrm{~m}$. First, the pasture protection strips of Haloxylon aphyllum were laid out, and after 2 years the reclamation and forage strips of Krascheninnikovia ceratoides and Calligonum aphyllum were laid out. Standard seedlings and planting machines SLCh-1 and SSN-1 were used for planting. The terrain is a slightly hilly plain. The soil is brown and sandy. Areas of wind-drifted sand are found in places along the strips. The ground water was not detected at a depth of $4 \mathrm{~m}$. The plant association is ephemeral (Avena fatua L., Anisantha tectorum L., Poa bulbosa, solitary Artemisia lerchiana).

Soil tillage for planting protective plantations on pasture plots was carried out according to the following options: continuous deep plowing to a depth of $40-45 \mathrm{~cm}$; partial deep plowing in order to form rows to a depth of 40-45 $\mathrm{cm}$ using the deep-cut ploughing machine KPG-250, followed by plowing the aisles to a depth of $22-25 \mathrm{~cm}$ in the spring and summer period; regular solid plowing to a depth of $22-25 \mathrm{~cm}$.

Field work on the study of successional processes, geobotanical description and accounting of vegetation productivity was carried out during geobotanical surveys, according to generally accepted methods and instructions [2]. Data from key plots were used to assess succession. Each plot was characterized by a detailed description of 4 sample plots (size $100 \mathrm{~m}^{2}$ ) by plant species diversity and indicators of its changes (number of species, life forms, structure of above-ground phytomass of herbaceous layer). An assessment of tree and shrub layer was based on taxonomic and morphological evaluation in the field conditions on 5 trial plots of rectangular shape, $0.25-0.30$ ha, where the average height, diameter, nature of preservation of species, \% of flowering and fruiting specimens were recorded [1]. Classification of plantations according to the value of state indices is as follows: healthy $1-1.5$; weakened 1.6-2.5; severely weakened 2.6-3.5; dying 3.6-4.5; dead more than 4.6.

The nomenclature of vascular plant species is based on the Cherepanov's summary [12].

\section{Results and discussion}

Monitoring of the current state of forest pastures on brown semi-desert soils and analysis of dynamics of successions of vegetation cover allows us to identify promising technologies restoration of degraded pastures, on the example of objects where the integrity and multi-layered structure of phytocenoses has been preserved.

High results of survival rate, integrity and growth of shrub species in all options of the experiment were obtained as a result of careful compliance with the technology of forest planting in the semi-desert zone, however, the undisputed advantages remain for the deep plowing preparation of soil [3]. The study results are presented in table 1. 
Table 1

Survival rate $(\%)$ of shrubs in pasture reclamation plantations, Priselskiy pasture plot

\begin{tabular}{|c|c|c|c|c|c|c|c|c|c|}
\hline \multirow{3}{*}{ Plant species assortment } & \multicolumn{9}{|c|}{ Soil tillage method } \\
\hline & \multicolumn{3}{|c|}{ Deep plowing } & \multicolumn{3}{|c|}{ Flat-cut } & \multicolumn{3}{|c|}{ Conventional } \\
\hline & 1978 & 1979 & 1980 & 1978 & 1979 & 1980 & 1978 & 1979 & 1980 \\
\hline Haloxylon aphyllum & 96.4 & 38.5 & 89.2 & 92.4 & 67.2 & 70.1 & 91.1 & 65.4 & - \\
\hline $\begin{array}{c}\text { Krascheninnikovia } \\
\text { ceratoides }\end{array}$ & 99.0 & 86.5 & 95.3 & 99.4 & 94.0 & 97.2 & 97.0 & 94.2 & - \\
\hline Calligonum aphyllum & 95.0 & 97.3 & 97.1 & 97.0 & 95.8 & - & 93.0 & 94.1 & - \\
\hline
\end{tabular}

Note: Planting was not carried out in the columns with a dash.

The low survival rate of Haloxylon aphyllum is explained by drying of the planting material during the deep plowing in 1979. Good indicators of survival rate of shrubs were also noted in other areas of the region in these years.

The results of 3-year observations of phytomass growth of shrub species showed that the maximum increase was observed in Krascheninnikovia ceratoides and Haloxylon aphyllum in pasture reclamation plantations in the second year of life. Haloxylon aphyllum can accumulate $0.7-0.9$ t/ha of dry mass with moderate grazing (60\% increase), and Krascheninnikovia ceratoides can accumulate $0.8-1.0 \mathrm{t} / \mathrm{ha}$, respectively. The yield of grassy vegetation was taken into account in interstrip spaces and open semi-desert, along with the determination of shrub phytomass.

The yield of air-dry grass mass was $0.69,0.52$ and $0.37 \mathrm{t} / \mathrm{ha}$ on the pasture protected by forest strips on the Priselskiy pasture plot in 1978, 1979 and 1980, respectively, and on an open pasture (control plot) it was 2-3 times less: 0.38 , 0.28 and $0.19 \mathrm{t} / \mathrm{ha}$. Productivity was $0.61 \mathrm{t} / \mathrm{ha}$ in the system of pasture protective strips over a nine-year observation period (1978-1986), control $-0.36 \mathrm{t} / \mathrm{ha}$. The increase in the yield of grasses under the protection of forest strips on the pasture plots was: by $0.17 \mathrm{t} / \mathrm{ha}$ - Cordon; by $0.21 \mathrm{t} / \mathrm{ha}$ - Sokolovskiy; by $0.11 \mathrm{t} / \mathrm{ha}$ - Railway.

After 2 years, the reclaimed plots (Priselskiy, Sokolovskiy, Railway and Roadside) were put into use after planting pasture protective strips. An intensive grazing of small cattle began in the amount of 1.5 ths heads during the growing season in disregard of enclosure pasturing. This had a negative impact on the growth of pasture grasses, and after 2 years, the yield of ephemeral plants was in control higher than in the inter-strip space of the Priselskiy pasture plot, since it was adjacent to the lands of the state forest fund. Cattle broke up the Haloxylon aphyllum plantings.

An analysis of the state of forest pastures revealed a change in the previous multi-layered structure, which lost the functional purpose of the following plots: Priselskiy in 1995, Sokolovskiy and Railway in 2000.

The Roadside and Cordon plots perform their functions due to their remoteness from populated areas (table 2). 
Table 2

The state of shrub vegetation in pasture-protective and reclamation-forage plantations, 2003

\begin{tabular}{|c|c|c|c|c|c|c|c|}
\hline \multirow{2}{*}{$\begin{array}{c}\text { Pasture } \\
\text { plot }\end{array}$} & Species & \multirow{2}{*}{$\begin{array}{c}\text { Age, } \\
\text { yrs }\end{array}$} & $\begin{array}{c}\text { Average } \\
\text { height, } \mathrm{m}\end{array}$ & $\begin{array}{c}\text { Preservation, } \\
\%\end{array}$ & \multicolumn{2}{|c|}{$\begin{array}{c}\text { Spring } \\
\text { moistening of } \\
\text { soil, cm }\end{array}$} & \\
\cline { 5 - 8 } & & & & $\begin{array}{c}\text { In the } \\
\text { Intrip } \\
\text { inter- } \\
\text { strip } \\
\text { space }\end{array}$ & $\begin{array}{c}\text { Ecological } \\
\text { state }\end{array}$ \\
\hline Cordon & $\begin{array}{c}\text { Haloxylon } \\
\text { aphyllum }\end{array}$ & 23 & $2.5 \pm 0.05$ & 53 & 65 & 57 & 2.0 \\
\hline \multirow{2}{*}{ Roadside } & $\begin{array}{c}\text { Haloxylon } \\
\text { aphyllum }\end{array}$ & 22 & $2.8 \pm 0.02$ & 68 & 71 & 63 & 1.8 \\
\cline { 2 - 7 } & $\begin{array}{c}\text { Kraschenin- } \\
\text { nikovia } \\
\text { ceratoides }\end{array}$ & 22 & $0.7 \pm 0.04$ & 73 & 73 & 68 & 1.5 \\
\hline
\end{tabular}

An assessment of successional changes over a 30-year period (2013 surveys) of the study area showed the state of the forest pastures (table 3).

Wormwood-cereals (bluegrass) associations are formed in the conditions of the Astrakhan semi-desert on pasture lands with a very low yield of about $0.3-0.4 \mathrm{t} / \mathrm{ha}$ in May, and after gazing and burning of vegetation in August $-0.06-0.2 \mathrm{t} / \mathrm{ha}$. This is due to the vegetation cover degradation, which cannot be restored due to increased pasture load, low autumn moisture reserves in soil and increased temperature during the growing season. Biodiversity is very low on the plots (8-19 species).

Studies have shown that the Roadside and Cordon plots have great biodiversity, and they preserve the tree and shrub layer after 35 years. Saxaul strips were preserved by $30 \%$ on the Roadside plot; their average height is $2.2 \mathrm{~m}$. Within the Cordon plot, the average height of Haloxylon aphyllum is $2.4 \mathrm{~m}$, the preservation is $45 \%$ (table 4 ).

The observations have shown that an increase in phytomass yield in the forest-agrarian ecosystems that are being formed can compensate the loss of annual productivity in 10-15 years after forest reclamation due to desertification, and provide an increase in fertility of reclaimed landscapes with full environmentally safe implementation of the agricultural resource potential of the territories in the future.

A monitoring of forest pastures gave the following results in terms of the state of plantings and the yield of grasses (table 5, 6).

The yield of grasses is greater than in spring period and is $0.75 \mathrm{t} / \mathrm{ha}$ in May within the Cordon plot, and $0.80 \mathrm{t} / \mathrm{ha}$ on the Roadside plot (table 5). The composition is Artemisia lerchiana (about $82 \%$ ) and Poa bulbosa (10\%). The yield of herbs does not increase at the end of August due to the lack of rainfall during the growing season (more weed poisonous herbs appear).

The best growth conditions for grassy ve getation are formed in the $30 \mathrm{~m}$ wide inter-strip space between pasture protective strips due to the best microclimatic characteristics. The yield of natural pasture vegetation was higher by $0.22-0.27 \mathrm{t} / \mathrm{ha}$ in both the spring and autumn periods by years. 
Table 3

Agroecological state of forest pastures of the Astrakhan semi-desert, 2013

\begin{tabular}{|c|c|c|c|c|c|c|}
\hline \multirow[b]{2}{*}{$\begin{array}{l}\text { Pasture } \\
\text { plot }\end{array}$} & \multirow[b]{2}{*}{$\begin{array}{c}\text { Year of } \\
\text { succession }\end{array}$} & \multicolumn{5}{|c|}{ Analysis of current state } \\
\hline & & $\begin{array}{c}\text { FRC, } \\
\text { terrain, } \\
\text { soil, } \\
\text { salinization } \\
1.5-2 \mathrm{~m}\end{array}$ & $\begin{array}{l}\text { Number } \\
\text { of } \\
\text { species, } \\
\text { pcs }\end{array}$ & $\begin{array}{l}\text { Composition of } \\
\text { phytomass, \% }\end{array}$ & Yield, t/ha & $\begin{array}{l}\text { State } \\
\text { of tree } \\
\text { and } \\
\text { shrub } \\
\text { layer }\end{array}$ \\
\hline $\begin{array}{l}\text { Prisels- } \\
\text { kiy }\end{array}$ & 36 & $\begin{array}{l}\text { II and } \\
\text { III FRC, } \\
\text { wavy, } \\
\text { sandy } \\
\text { loam } \\
\text { and light } \\
\text { loam, } \\
\text { slightly } \\
\text { solonetz }\end{array}$ & 8 & $\begin{array}{c}\text { Shrubs (Kraschenin- } \\
\text { nikovia ceratoides) - } \\
1 \% \text {; cereals - 20\%; } \\
\text { Artemisia lerchiana- } \\
19 \% \text {; motley grass - } \\
45 \% \text {; Anabasis, etc. } \\
\text { - } 15 \%\end{array}$ & $0.26 \pm 0.06$ & $\begin{array}{c}\text { Tree } \\
\text { layer } \\
\text { died } \\
\text { in } \\
1995\end{array}$ \\
\hline $\begin{array}{l}\text { Sokolov- } \\
\text { skiy }\end{array}$ & 36 & $\begin{array}{c}\text { II и III } \\
\text { FRC, } \\
\text { wavy, } \\
\text { salty, } \\
\text { sandy } \\
\text { loam and } \\
\text { light loam } \\
\text { in a com- } \\
\text { plex with } \\
\text { solonetz } \\
(10 \%) \\
\end{array}$ & 9 & $\begin{array}{c}\text { Shrubs (Kraschenin- } \\
\text { nikovia ceratoides) - } \\
1 \% \text {; cereals - } 29 \% \text {; } \\
\text { Artemisia arenaria- } \\
10 \% \text {; Artemisia } \\
\text { lerchiana }-10 \% \text {; } \\
\text { montley grass }-50 \%\end{array}$ & $0.25 \pm 0.05$ & $\begin{array}{l}\text { Tree } \\
\text { layer } \\
\text { died } \\
\text { in } \\
2000\end{array}$ \\
\hline Railway & 35 & $\begin{array}{l}\text { II и III } \\
\text { FRC, } \\
\text { wavy, } \\
\text { brown } \\
\text { sandy } \\
\text { loam }\end{array}$ & 10 & $\begin{array}{l}\text { Shrubs (Kraschenin- } \\
\text { nikovia ceratoides) - } \\
3 \% \text {; cereals - 30\%; } \\
\text { Artemisia lerchiana- } \\
27 \% \text {; montley } \\
\text { grass }-40 \%\end{array}$ & $0.38 \pm 0.06$ & $\begin{array}{l}\text { Tree } \\
\text { layer } \\
\text { died } \\
\text { in } \\
2000\end{array}$ \\
\hline $\begin{array}{l}\text { Road- } \\
\text { side }\end{array}$ & 34 & $\begin{array}{l}\text { II и III } \\
\text { FRC, } \\
\text { wavy, } \\
\text { sandy } \\
\text { loam } \\
\text { and light } \\
\text { loam, } \\
\text { slightly } \\
\text { solonetz }\end{array}$ & 19 & $\begin{array}{c}\text { Shrubs (Kraschenin- } \\
\text { nikovia ceratoides) - } \\
10 \% \text {; cereals - } 30 \% \text {; } \\
\text { Artemisia lerchiana - } \\
30 \% \text {; montley grass - } \\
30 \%\end{array}$ & $0.59 \pm 0.16$ & $\begin{array}{l}\text { Good } \\
\text { and } \\
\text { satis- } \\
\text { fac- } \\
\text { tory }\end{array}$ \\
\hline Cordon & 36 & $\begin{array}{l}\text { II FRC, } \\
\text { wavy, } \\
\text { brown } \\
\text { sandy } \\
\text { loam }\end{array}$ & 14 & $\begin{array}{c}\text { Cereals }-50 \% \\
\text { Artemisia lerchiana- } \\
20 \% \text {; montley } \\
\text { grass }-30 \%\end{array}$ & $0.47 \pm 0.09$ & $\begin{array}{l}\text { Satis- } \\
\text { fac- } \\
\text { tory }\end{array}$ \\
\hline
\end{tabular}

Note: Classification of arid pastures. I FRC: desertified pastures with fine and medium barkhan sands and strongly eroded soils. II FRC: pastures on overgrown and weakly overgrown sands. III FRC: pastures with deflation-prone loamy-sandy soils. IV FRC: pastures on loamy and clayey deflation soils. 
Table 4

Bioecological characteristics of tree species populations in forest pastures of the Astrakhan semi-desert, 2013

\begin{tabular}{|c|c|c|c|c|c|c|c|c|}
\hline \multirow{2}{*}{$\begin{array}{c}\text { Pasture } \\
\text { plot }\end{array}$} & Species & $\begin{array}{c}\text { Age, } \\
\mathrm{yrs}\end{array}$ & $\begin{array}{c}\text { Average } \\
\text { height, } \\
\mathrm{m}\end{array}$ & $\begin{array}{c}\text { Crown, } \\
\mathrm{m}\end{array}$ & $\begin{array}{c}\text { Trunk, } \\
\mathrm{cm}\end{array}$ & $\begin{array}{c}\text { Average diameter } \\
\text { skeletal } \\
\text { bran- } \\
\text { ches, } \\
\text { pcs }\end{array}$ & $\begin{array}{c}\text { Preserva- } \\
\text { tion, } \%\end{array}$ & $\begin{array}{c}\text { Ecolo- } \\
\text { gical } \\
\text { state }\end{array}$ \\
\hline $\begin{array}{c}\text { Road- } \\
\text { side }\end{array}$ & $\begin{array}{c}\text { Haloxy- } \\
\text { lon } \\
\text { aphyl- } \\
\text { lum }\end{array}$ & 34 & $2.2 \pm 0.02$ & $1.4 \pm 0.04$ & $12.5 \pm 0.8$ & 6 & 30 & 2 \\
\hline $\begin{array}{c}\text { Cor- } \\
\text { don }\end{array}$ & & 36 & $2.4 \pm 0.04$ & $1.6 \pm 0.09$ & $14.5 \pm 1.2$ & 7 & 45 & 2 \\
\hline
\end{tabular}

Note: The classification of plantings according to the value of state indices is as follows: healthy $1-1.5$, weakened 1.6-2.5, severely weakened 2.6-3.5, dying 3.6-4.5, dead $>4.6$.

A survey of forest pastures in the spring of 2007-2010 showed that forage plants of various species predominate in pastures due to the protection strips, while species diversity is poorer in open pastures. Mainly, the following forage plants are represented: Alyssum desertorum Stapf., Anisantha tectorum, Kochia prostrata, Poa bulbosa, Elytrigia repens, Setaria viridis L., Ceratocarpus arenarius L., Artemisia lerchiana under the protection of 30-year-old strips of Saxaula aphyllum.

Table 5

Yield of natural vegetation on pastures (2002-2005)

\begin{tabular}{|c|c|c|c|}
\hline \multirow{2}{*}{$\begin{array}{l}\text { Year of } \\
\text { research }\end{array}$} & \multicolumn{2}{|c|}{ Dry weight, $\mathrm{t} / \mathrm{ha}$} & \multirow[b]{2}{*}{ Deviation from control } \\
\hline & Inter-strip space & $\begin{array}{l}\text { Open pasture } \\
\text { (control) }\end{array}$ & \\
\hline \multicolumn{4}{|c|}{ Cordon pasture plot } \\
\hline 2002 & $\frac{1.66}{0.18}$ & $\frac{1.45}{0.12}$ & $\frac{0.22}{0.06}$ \\
\hline 2003 & $\frac{0.17}{0.09}$ & $\frac{0.12}{0.05}$ & $\frac{0.05}{0.04}$ \\
\hline 2004 & $\frac{0.84}{0.8}$ & $\frac{0.83}{0.65}$ & $\frac{0.01}{0.15}$ \\
\hline 2005 & $\frac{0.75}{1.0}$ & $\frac{0.60}{0.72}$ & $\frac{1.15}{0.27}$ \\
\hline \multicolumn{4}{|c|}{ Roadside pasture plot } \\
\hline 2003 & $\frac{0.18}{0.13}$ & $\frac{0.12}{0.07}$ & $\frac{0.06}{0.06}$ \\
\hline 2004 & $\frac{0.82}{0.41}$ & $\frac{0.60}{0.35}$ & $\frac{0.22}{0.06}$ \\
\hline 2005 & $\frac{0.80}{0.74}$ & $\frac{0.69}{0.67}$ & $\underline{0.11}$ \\
\hline
\end{tabular}

Note: Spring yield of herbs in the numerator (May); and denominator (August). 
A wormwood-ephemeral association with inedible plants (Anabasis aphylla L., etc.) prevails in open pastures (control).

The distribution of phytomass by layers during the research period is presented in Table 6.

Table 6

Productivity of grasses under the protection of RFP and open steppe in the groundlevel aerotope of pasture phytocenosis (May 2007-2010)

\begin{tabular}{|c|c|c|c|c|c|c|}
\hline \multirow{3}{*}{ Year } & \multicolumn{6}{|c|}{ Air-dry weight, $t /$ ha } \\
\hline & \multicolumn{2}{|c|}{ Total } & \multicolumn{2}{|c|}{ Edible } & \multicolumn{2}{|c|}{ Inedible } \\
\hline & $0-14 \mathrm{~cm}$ & $15-30 \mathrm{~cm}$ & $0-14 \mathrm{~cm}$ & $15-30 \mathrm{~cm}$ & $0-14 \mathrm{~cm}$ & $15-30 \mathrm{~cm}$ \\
\hline \multirow{2}{*}{2007} & 0.19 & 0.21 & 0.14 & 0.16 & 0.05 & 0.05 \\
\hline & $\overline{0.15}$ & $\overline{0.08}$ & $\overline{0.12}$ & $\overline{0.06}$ & $\overline{0.03}$ & $\overline{0.02}$ \\
\hline \multirow{2}{*}{2008} & $\underline{0.41}$ & $\underline{0.17}$ & $\underline{0.28}$ & $\underline{0.12}$ & $\underline{0.12}$ & $\underline{0.04}$ \\
\hline & 0.23 & $\overline{0.22}$ & 0.17 & 0.19 & 0.06 & $\overline{0.03}$ \\
\hline \multirow{2}{*}{2009} & $\underline{0.38}$ & $\underline{0.14}$ & $\underline{0.25}$ & $\underline{0.07}$ & $\underline{0.13}$ & $\underline{0.06}$ \\
\hline & 0.22 & 0.11 & 0.16 & 0.08 & 0.06 & 0.03 \\
\hline \multirow{2}{*}{2010} & $\underline{0.32}$ & $\underline{0.13}$ & 0.21 & 0.07 & 0.11 & 0.06 \\
\hline & $\overline{0.26}$ & $\overline{0.10}$ & $\overline{0.15}$ & $\overline{0.06}$ & $\overline{0.11}$ & $\overline{0.04}$ \\
\hline
\end{tabular}

Note: RFP - reclamation and forage plantations; in the numerator - the yield of pastures under the protection of RFP; in the denominator - the yield of pastures in the open steppe.

The yield of grasses in 2009 is less than in 2008, and in 2010 it is even lower due to the dry spring.

At present, the Priselskiy plot is $70 \%$ plowed for vegetable crops. Haloxylon aphyllum is preserved on the tops of the Baer knolls. The state is satisfactory.

The Cordon plot retains reclamation functions on the lands of the state forest fund. The state of Haloxylon aphyllum strips is satisfactory.

Analysis of species composition and life forms of forest pastures showed that under extremely arid conditions and soil mobility, unregulated intensive grazing, the tree layer begins to thin out quickly. Up to 40 years, only clumps or single specimens survive. However, they play an important zoogenic and phytogenic role, contributing to the stability of plant communities. The shrub layer retains high productive and generative capacities for a long time (up to 45 years) on the Cordon plot.

\section{Conclusion}

In General, it should be noted that the positive impact is observed everywhere in previously phytoreclamed areas for 34-36 years of succession changes.

Assessing the impact of the tree and shrub layer on biodiversity, it is necessary to distinguish forest pastures: the Roadside plot and the Cordon plot (14-19 species), where pasture protection strips of Haloxylon aphyllum and reclamation-forage plantations of Krascheninnikovia ceratoides and Calligonum aphyllum were planted.

Comparing the dynamics of composition and structure of ecological groups of forest pastures of the arid zone, it should be noted that the decrease in the proportion of biomass of forage species revealed everywhere in case of low moisture reserves due to the reduction of rainfall during October - December 2 times (by $30 \mathrm{~mm}$ ) against the middle annual indicators, and also an increase in the load onto these areas due to a lack of forage in the neighboring pastures, where very low yields have been observed for 10 years. 
These environmental factors led to a decrease in forage weight from $80-90 \%$ to $40-50 \%$. At the same time, there was a sharp increase in the proportion of poisonous species from $1-3 \%$ to $8-11 \%$, as well as ruderal species. The forecast of successions should be expected to be unfavorable, i.e. the further dominance of species that are not suitable for animals is probable. Phytocenoses will be formed as ephemeral and montley grasses, where inedible species will play a protective role. Therefore, it is necessary to carry out the phytoreclamation and forest reclamation work urgently.

The conducted research made it possible to assess the long-term reclamation effect. It showed that the advantage of created forest pastures is manifested not only in terms of increasing the phytoproductivity of forest-reclaimed territories, but also in terms of increasing biodiversity, forming more stable populations and phytocenoses, which contribute to prolonging a productive longevity and create more sustainable agricultural landscapes.

\section{REFERENCES}

1. Агролесомелиорация / под ред. А.Л. Иванова, К.Н. Кулика. Волгоград: ВНИАЛМИ, 2006. 746 с.

Agroforestry. Ed. by A.L. Ivanov, K.N. Kulik. Volgograd, VNIALMI Publ., 2006. 746 p. 2. Агроэкология / под ред. В.А. Черникова, А.И. Черкеса. М.: Колос, 2000. 536 с. Agroecology. Ed. by V.A. Chernikov, A.I. Cherkes. Moscow, Kolos Publ., 2000. 536 p.

3. Асмачкин А.П., Лепеско В.В., Терюков А.Г. Состояние и перспективы развития защитного лесоразведения в Астраханской области. Волгоград, 1989. 155 с.

Asmachkin A.P., Lepesko V.V., Teryukov A.G. State and Prospects for the Development of Protective Afforestation in the Astrakhan Region. Volgograd, 1989. 155 p.

4. Вдовенко A.B. Экологические проблемы пастбищного животноводства Северо-Западного Прикаспия // Агро XXI. 2012. № 7-9. С. 45-47.

Vdovenko A.V. Environmental Problems of Pasture Cattle Breeding in the NorthWestern Caspian Region. Agro XXI, 2012, no.7-9, pp. 45-47.

5. Крючков С.Н., Маттис Г.Я. Лесоразведение в засушливых условиях. Волгоград: ВНИАЛМИ, 2014. $301 \mathrm{c.}$

Kryuchkov S.N., Mattis G.Ya. Afforestation in Arid Conditions. Volgograd, VNIALMI Publ., 2014. 301 p.

6. Кулигин C.M. Вегетативная продуктивность, качественная характеристика травянистых растений и мелиоративно-кормовых насаждений на пастбищах Астраханского Заволжья // Бюл. Всесоюз. науч.-исслед. ин-та агролесомелиорации. 1985. № 1(44). C. 56-58.

Kuligin S.M. Vegetative Productivity, Qualitative Characteristics of Herbaceous Plants and Reclamation-Forage Plantations in Pastures of the Astrakhan Transvolga Region. Byulleten' Vsesoyuznogo nauchno-issledovatel'skogo instituta agrolesomelioratsii, 1985, no. 1(44), pp. 56-58.

7. Манаенков А.С. Лесомелиорация арен засушливой зоны. 2-е изд., перераб. и доп. Волгоград: ФНЦ агроэкологии РАН, 2018. 428 с.

Manaenkov A.S. Forest Reclamation of Sandy Terraces of Arid Zone. Volgograd, FRC of Agroecology RAS Publ., 2018. 428 p.

8. Озолин Г.П. Древесные и кустарниковые породы, применяемые в защитном лесоразведении юго-восточных районов страны // Агролесомелиорация. М.: Лесн. пром-сть, 1979. С. 132-148.

Ozolin G.P. Tree and Shrub Species Used in Protective Afforestation of the SouthEastern Regions of the Country. Agroforestry. Moscow, Lesnaya promyshlennost' Publ., 1979, pp. 132-148. 
9. Петров В.И., Фомичев Г.Д., Васильев Ю.И. Новые виды защитных лесонасаждений для целей животноводства // Бюл. Всесоюз. науч.-исслед. ин-та агролесомелиорации. 1985. № 1(44). С. 27-30.

Petrov V.I., Fomichev G.D., Vasil'yev Yu.I. New Types of Protective Forest Plantations for Cattle Breeding Purposes Byulleten'Vsesoyuznogo nauchno-issledovatel'skogo instituta agrolesomelioratsii, 1985, no. 1(44), pp. 27-30.

10. Рыбашлыкова Л.П., Беляев А.И., Пугачёва А.М. Мониторинг сукцессионных изменений пастбищных фитоценозов в «потухших» очагах дефляции Северо-Западного Прикаспия // Юг России: экология, развитие. 2019. Т. 14, № 4. С. 78-85.

Rybashlykova L.P., Belyaev A.I., Pugacheva A.M. Monitoring Successional Changes in Pasture Phytocenoses in in 'Exhausted' Areas of Deflation in the North-West Caspian Region. Úg Rossii: èkologiâ, razvitie [South of Russia: ecology, development], 2019, vol. 14, no, 4 pp. 78-85. DOI: https://doi.org/10.18470/1992-1098-2019-4-78-85

11. Akhmedenov K.M. Analysis of the Afforestation Status in the Arid Conditions of Western Kazakhstan. Biology Bulletin, 2018, vol. 45, iss. 10, pp. 1153-1158. DOI: https://doi.org/10.1134/S1062359018100023

12. Czerepanov S.K. Vascular Plants of Russia and Adjacent States (the Former USSR). Cambridge, Cambridge University Press, 2007. 532 p.

13. Gamoun M., Hanchi B., Neffati M. Dynamic of Plant Communities in Saharan Rangelands Tunisia. Arid Ecosystems, 2012, vol. 2, iss. 2, pp. 105-110. DOI: https://doi.org/10.1134/S2079096112020060

14. Kulik K.N., Barabanov A.T., Manaenkov A.S. Forecasting the Development of Protective Afforestation in Russia until 2020. Studies on Russian Economic Development, 2015, vol. 26, iss. 4, pp. 351-358. DOI: https://doi.org/10.1134/S1075700715040073

15. Lepesko V.V., Belyaev A.I., Pleskachev Yu.N., Pugacheva A.M., Rybashlykova L.P. Monitoring the State and Ecological Ameliorative Effect of Tree and Shrub Coulisse and Row Plantings on Pastures in the Arid Conditions of the Northern Caspian. IOP Conference Series: Earth and Environmental Science, 2019, vol. 341, art. 012103. DOI: https://doi.org/10.1088/1755-1315/341/1/012103

16. Padilla F.M., Pugnaire F.I. The Role of Nurse Plants in the Restoration of Degraded Environments. Frontiers in Ecology and the Environment, 2006, vol. 4, iss. 4, pp. 196-202. DOI: $\underline{\text { https://doi.org/10.1890/1540-9295(2006)004[0196:TRONPI]2.0.CO;2 }}$

17. Radochinskaya L.P., Kladiev A.K., Rybashlykova L.P. Production Potential of Restored Pastures of the Northwestern Caspian. Arid Ecosystems, 2019, vol. 9, iss. 1, pp. 51-58. DOI: https://doi.org/10.1134/S2079096119010086

18. Sapanov M.K, Sizemskaya M.L., Akhmedenov K.M. Reclamation Stages and Modern Use of Arid Lands in the Northern Caspian Region. Arid Ecosystems, 2015, vol. 5, iss. 3, pp. 188-193. DOI: https://doi.org/10.1134/S2079096115030105

19. Yan Q., Zhu J., Zheng X., Jin C. Causal Effects of Shelter Forests and Water Factors on Desertification Control during 2000-2010 at the Horqin Sandy Land Region, China. Journal of Forestry Research, 2015, vol. 26, iss. 1, pp. 33-45. DOI: https://doi.org/10.1007/ s11676-014-0012-x

20. Zethof J.H.T., Cammeraat E.L.H., Nadal-Romero E. The Enhancing Effect of Afforestation over Secondary Succession on Soil Quality under Semiarid Climate Conditions. Science of the Total Environment, 2019, vol. 652, pp. 1090-1101. DOI: https://doi.org/10.1016/j.scitotenv.2018.10.235 


\section{ОЦЕНКА ПРИРОДНЫХ И ЛЕСОМЕЛИОРИРОВАННЫХ КОРМОВЫХ УГОДИЙ В УСЛОВИЯХ ПОЛУПУСТЫНИ НА ЮГЕ РОССИИ}

Л.П. Рыбашлыкова ${ }^{1}$, канд. с.-х. наук, вед. науч. сотр.; ResearcherID: $\underline{W-4197-2018}$, ORCID: https://orcid.org/0000-0002-3675-6243

В.В. Лепеско ${ }^{2}$ канд. с.-х. наук, вед. науч. сотр.; ResearcherID: AAD-9953-2020, ORCID: https://orcid.org/0000-0003-2111-9636

${ }^{1}$ Федеральный научный центр агроэкологии, комплексных мелиораций и защитного лесоразведения РАН, просп. Университетский, д. 97, г. Волгоград, Россия, 400062; e-mail: ludda4ka@mail.ru

${ }^{2}$ Богдинская научно-исследовательская агролесомелиоративная опытная станция, ул. БОС, д. 1., г. Харабали, Астраханская область, Россия, 416010

Аннотация. Бессистемное использование пастбищ стало одним из факторов нарушения их естественной растительности. Поэтому в Прикаспийском регионе в середине $\mathrm{XX}$ в. были проведены лесомелиоративные работы и созданы значительные площади полосных насаждений из кустарников. На территории аридной зоны России одной из важнейших задач в области научного обеспечения защитного лесоразведения является совершенствование методов и приемов обустройства, повышение долговечности, экологической, сельскохозяйственной и утилитарной эффективности насаждений. Исследование направлено на определение долгосрочного воздействия облесения на функционирование пастбищных экосистем. Также было изучено влияние древесно-кустарникового яруса на биоразнообразие, продуктивность растительного покрова пастбищ. Объектом исследования стали насаждения лесных полос на мелиорированных пастбищах. Использованы материалы биомониторинга, геоботанической съемки и полевых опытов с применением типовых методик лесной таксации. Закладывали пробные площади прямоугольной формы 0,25-0,30 га. Проводили подробное описание местоположения участка, состава почвы, времени, способа и технологии создания насаждений, а также комплексную оценку роста и долговечности древесно-кустарниковых культур. Изучение сукцессионных процессов растительного покрова осуществляли с применением данных ключевых участков. Результаты показали, что в зоне полупустыни для обеспечения высокой приживаемости, сохранности и роста кустарниковых пород при различных технологиях подготовки почвы преимущество остается за плантажной методикой. Как следует из опытов, кустарниковый ярус до 45 лет сохраняет продукционные и генеративные способности. Высоким ценозообразующим потенциалом и устойчивостью обладают пастбищезащитные полосы из Haloxylon aphyllum и мелиоративно-кормовые насаждения из Krascheninnikovia ceratoides и Calligonum aphyllum. В полузасушливых районах облесение с помощью кустарников является наилучшим способом улучшения и восстановления пастбищ.

For citation: Rybashlykova L.P., Lepesko V.V. Assessment of Natural and Forest Reclaimed Forage Lands in Semi-Desert Conditions in Southern Russia // Изв. вузов. Лесн. журн. 2021. № 3. C. 37-48. DOI: 10.37482/0536-1036-2021-3-37-48

Ключевые слова: аридная зона, бурые почвы, лесопастбища, геоботанические описания, многоярусная структура фитоценозов, мелиорированные кормовые угодья, полупустыня.

Поступила 23.03.20 / Received on March 23, 2020 